\title{
Guillain-Barré syndrome associated with hepatitis A in a male homosexual
}

\author{
A DUNK, W J JENKINS, AND S SHERLOCK \\ From the Academic Department of Medicine, Royal Free Hospital School of Medicine, London
}

SUMMARY A 48-year-old male homosexual developed the Guillain-Barré syndrome in association with acute hepatitis. The hepatitis A virus was almost certainly transmitted sexually. Since the incidence of viral hepatitis is high in active male homosexuals, they are particularly at risk of developing such complications.

\section{Introduction}

Sexually transmitted viral hepatitis is an increasingly important problem in active male homosexuals. ${ }^{12}$ Although hepatitis B infection usually causes a more severe illness than hepatitis A and may cause chronic liver disease, hepatitis $\mathbf{A}$ is more common ${ }^{1}$ and may occasionally cause other serious complications as well as fulminant hepatic failure. We report the potentially fatal complication of Guillain-Barré syndrome with serologically confirmed hepatitis $A$ in an active male homosexual.

\section{Case report}

A previously healthy 48-year-old man felt unwell with headache, fatigue, and myalgia. Three days later he noticed dark urine and paraesthesia in his hands and feet. The next day his legs and upper arms were weak and he became jaundiced.

He had not had any injections, tattoos, or blood transfusions and did not abuse drugs. He had not travelled abroad recently nor had any contact with jaundiced people. Nevertheless, he had been an active homosexual for 10 years. He had between 20 and 25 new partners each month, with whom he had oroanal contact.

\section{CLINICAL FINDINGS}

On admission to hospital four days after the onset of his symptoms he was slightly jaundiced, but there were no signs of chronic liver disease. There were, however, pronounced neurological abnormalities.

Address for reprints: Dr W J Jenkins, Academic Department of Medicine, Royal Free Hospital School of Medicine, Pond Street, London NW3 2QG

Accepted for publication 10 January 1982
He was hypotonic and areflexic. Power was generally reduced in the arms and legs, particularly proximally. Joint-position sense and vibration sense were diminished in the feet, but sensory testing was otherwise normal.

\section{LABORATORY FINDINGS}

The serum liver function tests were abnormal. Serum aspartate aminotransferase was 237 IU/l (normal 5-40 IU/l) and alkaline phosphatase $458 \mathrm{IU} / \mathrm{l}$ (normal 30-110 IU/l); serum bilirubin concentration was $29 \mu \mathrm{mol} / \mathrm{l}$ (normal 5-17 $\mu \mathrm{mol} / \mathrm{l}$ ). Hepatitis B surface antigen ( $\mathrm{HBsAg}$ ) and antibody (HBsAb), hepatitis $\mathrm{B}$ core antigen ( $\mathrm{HBcAg})$, and IgM antibody were all absent; serological test results for recent Epstein-Barr virus and cytomegalovirus infections were negative. Hepatitis A IgM antibody measured by radioimmunoassay was detectable.

\section{COURSE OF ILLNESS}

The weakness of the limbs progressed, and three days after admission the patient was unable to walk or feed himself. The following day he developed bilateral lower motor neurone VII cranial nerve palsies and was unable to sit up. He also became dysarthric, but swallowing and the gag reflex remained normal.

A lumbar puncture showed normal pressure (100 $\mathrm{mm} \mathrm{Hg}$ ); the cerebrospinal fluid contained no cells, $0.3 \mathrm{~g} / \mathrm{l}$ protein, and $3.5 \mathrm{mmol} / \mathrm{l}(63 \mathrm{mg} / 100 \mathrm{ml})$ glucose. In view of these somewhat surprising results nerve conduction studies were performed. Motor conduction in the right median nerve was reduced at $37 \mathrm{~m} / \mathrm{s}$ and the terminal latency was prolonged $(6.8 \mathrm{~ms})$. The $F$ wave latency with elbow stimulation was increased $(37 \mathrm{~ms})$. No sensory nerve action potential was detectable. These abnormalities of conduction are consistent with the clinical diagnosis of the Guillain-Barré syndrome. 
The patient made a rapid recovery from hepatitis. By the eleventh day after admission the prothrombin time had improved sufficiently for a liver biopsy to be performed safely; it showed the changes of recent acute hepatitis. Meanwhile, the patient was also recovering power in the limbs and he could walk with a frame 12 days after admission. He was well enough to be discharged three days later. When he was next seen two months afterwards, power in the limbs was normal, but the VII cranial nerve palsies persisted. Five months after the initial symptoms there was further improvement, but a mild left VII cranial nerve palsy remained.

\section{Comment}

The presence of IgM antibody against hepatitis A virus identified it as the cause of the acute hepatitis in this patient. Hepatitis A is now considered to be one of the enteric infections that are transmitted sexually among homosexual men. Our patient, who was frequently the oral partner in oroanal contact, was particularly at risk, since Corey and Holmes showed that the acquisition of hepatitis A infection was correlated with this form of sexual activity. ${ }^{2}$

The progressive symmetrical polyradiculopathy, which developed in this patient in association with the acute hepatitis, is typical of the Guillain-Barré syndrome. The diagnosis is essentially clinical and supported by nerve conduction studies. ${ }^{3}$ Although the protein content of the CSF is usually high, it may be normal, especially in the early stages, and in some cases remains so. ${ }^{4}$

The major danger in the Guillain-Barre syndrome is paralysis of the respiratory muscles, but the prognosis is generally good. Approximately $75 \%$ of patients recover totally, ${ }^{5}$ and the delayed improvement of the facial nerve palsies in this patient is typical.
The Guillain-Barré syndrome is often associated $\stackrel{\Phi}{\overparen{D}}$ with some form of bacterial or viral infection. Respiratory infections are the most common. ${ }^{6}$ The association with hepatitis is unusual. In a series of 1100 cases of Guillain-Barré syndrome Leneman ${ }^{6} \stackrel{\text { क }}{\rightarrow}$ reported 11 associated with acute hepatitis. This report $^{6}$ and others ${ }^{78}$ preceded the development of specific serological tests to identify the hepatitis viruses. Subsequently, a few cases of Guillain-Barré syndrome associated with hepatitis B have been $\aleph^{\circ}$ reported, ${ }^{9-11}$ but there has only been one previous report associated with hepatitis $\mathrm{A} .^{12}$

Because the incidence of viral hepatitis is high in active male homosexuals, they may be particularly at risk of developing such complications.

\section{References}

1. Fawaz KA, Matloff DS. Viral hepatitis in homosexual men. Gastroenterology 1981;81:537-8.

2. Corey L, Holmes KK. Sexual transmission of hepatitis $\mathbf{A}$ in 윽 homosexual men. N Engl J Med 1980;302:435-8.

3. Kimura J. Proximal versus distal slowing in motor nerve conduction velocity in the Guillain-Barré syndrome. Ann Neurol 1978; 3:344-50.

4. Masucci EF, Kurtzke JF. Diagnostic criteria for the Guillain Barré syndrome. J Neurol Sci 1971;13:483-501.

5. Adams RD, Asbury AK. Disease of the peripheral nervous $\rightarrow$ system. In: Isselbacher $\mathrm{KJ}$, Adams RD, Braunwald E, Petersdorf RG, Wilson JD, eds. Harrison's Principles of Internal Medicine. New York: McGraw-Hill, 1980:2027-39.

6. Leneman F. The Guillain-Barré syndrome. Arch Int Med 1966; 118: 139-44.

7. Lescher FG. The nervous complications of infective hepatitis Br Med J 1944; i: 544-6.

8. Asbury AK. Hepatic neuropathy. In: Dyck PJ, Thomas PK, Lambert EH, eds. Peripheral Neuropathy. Philadelphia: WB Saunders, 1975;993-8.

9. $\mathrm{Ng} \mathrm{P}$, Powell L, Campbell CB. Guillain-Barré syndrome during preicteric phase of acute type B viral hepatitis. Aust NZ J Med 1975; 5:367-9.

10. Niermeijer P, Gips $\mathrm{CH}$. Guillain-Barré syndrome in acute HBsAg-positive hepatitis. Br Med J 1975; iv:732-3.

11. Berger JR, Ayyar DR, Sheremata WA. Guillain-Barre syndrome complicating acute hepatitis B. Arch Neurol 1981 38: 366-8.

12. Johnston CLW, Schwartz M, Wansbrough-Jones MH. Acute inflammatory polyradiculoneuropathy following type A viral hepatitis. Post Grad Med J 1981;57:647-8. 